\title{
Innovations
}

\section{Narrating Arab women's voices and disability: Notes on the Flesh, a biomythography}

\author{
Medical Humanities in the Middle East Conference \\ November 17-18, 2018 \\ Doha, Qatar
}

\section{Authors}

\section{Shahd Alshammari ${ }^{\star \star}$}

\section{Abstract}

Given the lack of illness narratives in Arabic literature and Anglophone literature, the author has written a collection of short stories, partly a memoir dealing with her own disability. The work is entitled Notes on the Flesh. It deals with illness and disability in Kuwait and the Middle East in general. Writing women's lives is crucial, and even more so is the writing of disabled female protagonists into the existing literature on women. Only through creative writing is there a sense of reclaiming voice and agency. Patient voices are often unheard and illness narratives are almost unheard of in the MENA region. The author's own experience as a Disability Studies scholar diagnosed with a neurological disorder has allowed her to write the first illness narrative in the voice of a Kuwaiti

'Gulf University for Science and Technology, Kuwait City, Kuwait *Email: alshammari.s@gust.edu.kw

Shahd Alshammari iD https://orcid.org/0000-0002-2364-3231 woman. The author's literary training has fostered her own interest in 'companion texts' and authors who have explored illness. Such authors include Audre Lorde, Nancy Mairs, and Arthur Frank. All these authors are Western and have written their respective illness narratives paying attention to their societies. To correct this gap in the literary canon of illness narratives, the author has embarked on this journey of writing her voice into the canon. Notes on the Flesh is a collection that is part-memoir, part fictional, interrogating what it means to be 'disabled' and different in the MENA region. The book is the first illness narrative written in English from the point of view of an Arab female protagonist. It has participated at the Emirates Literature Festival (March 2017), the Malta Book Festival, and continues to be read at universities.

\section{Conflicts of interest: None.}

Funding sources: None.

\section{Cite this article as:}

Alshammari, S. Narrating Arab women's voices and disability: Notes on the Flesh, a biomythography. In: Weber AS, Verjee MA, editors. Proceedings of the 1st International Conference on Medical Humanities in the Middle East [Internet]; 2018 Nov 17-18: Doha, Qatar: Innovations in Global Health Professions Education; 2019 March. p. 20-21. (Innovations in Global Health Professions Education; vol. 2019, spec. no.: 1). https://dx.doi. org/10.20421/ighpe2019.01.06

This is an open access article distributed under the terms of the Creative Commons Attribution license CC BY 4.0, which permits unrestricted use, distribution and reproduction in any medium, provided the original work is properly cited. 


\section{About the author}

Shahd Alshammari holds a PhD in English from the University of Kent, Canterbury. She is currently Assistant Professor at Gulf University for Science and Technology in Kuwait. Her research interests include madness in literature, Disability Studies, and gender studies. Her work includes Literary Madness in British, Postcolonial, and Bedouin Women's Writing (2016), Notes on the Flesh (2017), and Once Upon a Life...There Was Time (2018). Her essays and articles have appeared in Journal of Middle East Women's Studies, Journal of Literary and Cultural Disability Studies, Sukoon, Arab Journal for the Humanties. 